\title{
Color and expressiveness in the construction timbers by means surface treatments with acids
}

\author{
Color y expresividad en las maderas de construcción mediante tratamiento superficial con \\ ácidos
}

Francisco Lora Toro (Main and Corresponding Author)

Universidad Politécnica de Madrid, Departamento de Construcción y Tecnología Arquitectónicas

Escuela Técnica Superior de Arquitectura

Av. Juan de Herrera, 4, 28040 Madrid (Spain)

francisco.lora.toro@alumnos.upm.es / fltap21@gmail.com

\section{Alfonso García Santos \\ Universidad Politécnica de Madrid, Departamento de Construcción y Tecnología Arquitectónicas Escuela Técnica Superior de Arquitectura}

Av. Juan de Herrera, 4, 28040 Madrid (Spain)

alfonso.garciasantos@upm.es

\section{Antonio Rodríguez Rodríguez}

Universidad Politécnica de Madrid, Laboratorio de Materiales de Construcción

Escuela Técnica Superior de Arquitectura

Av. Juan de Herrera, 4, 28040 Madrid (Spain)

antonio.rodriguez.rodriguez@upm.es

Manuscript Code: 792

Date of Acceptance/Reception: 29.07.2018/01.08.2017

DOI: $10.7764 /$ RDLC.17.2.183

\section{Abstract}

The aim of this research is to compare the uniformity of the color histograms of the RGB color space between the traditional surface treatment with fire against the controlled surface treatment of colorless acids in liquid state on construction timbers, developed by the authors. A "conceptual translation" is proposed as a starting point, from the processes applied on construction timbers with treatments by means of fire (whose aim is not the color) to controlled surface treatment of colorless acids in liquid state on construction timbers. The color histograms of the RGB color space are compared of both treatments and it is concluded that the controlled surface treatment of colorless acids in liquid state on construction timbers obtains a more uniform distribution of color histograms than the traditional surface treatment with fire.

Key words: Timber, colorless acids, color, surface treatment.

\section{Resumen}

El objetivo de esta investigación es comparar la uniformidad de los histogramas de color del espacio RGB entre el tratamiento superficial tradicional con fuego y el tratamiento superficial controlado con ácidos sobre maderas de construcción, desarrollado por los autores. Como punto de partida se propone una "traslación conceptual", de los tratamientos mediante fuego sobre maderas de construcción (cuyo objetivo no es el color) al tratamiento superficial controlado de ácidos incoloros en estado líquido sobre las maderas de construcción. Se comparan los histogramas de color del espacio RGB de ambos tratamientos y se llega a la conclusión que el tratamiento superficial controlado con ácidos incoloros en estado líquido sobre las maderas de construcción obtiene una distribución más uniforme de los histogramas de color que el tratamiento superficial tradicional con fuego.

The aim of this research is to compare the uniformity of the color histograms of the RGB color space between the traditional surface treatment with fire against the controlled surface treatment of colorless acids in liquid state on construction timbers, developed by the authors.

The approach of this research uses like premises or starting point, the process of traditional surface treatment with fire on construction timbers and by another the controlled surface application of colorless acids in liquid state on construction timbers. In function of these premises, it is established one "duality parallel" between the process of traditional surface treatment with fire on construction timbers and the controlled surface treatment with colorless 
acids, unchaining one "conceptual translation", between both treatments. A "conceptual translation" is proposed by authors, from the processes applied on construction timbers with traditional treatments to surface application of colorless acids in liquid state on the construction timbers, generating a layer of superficial external on construction timbers (Figure 1).

Figure 1. Conceptual translation. Source: Self elaboration.

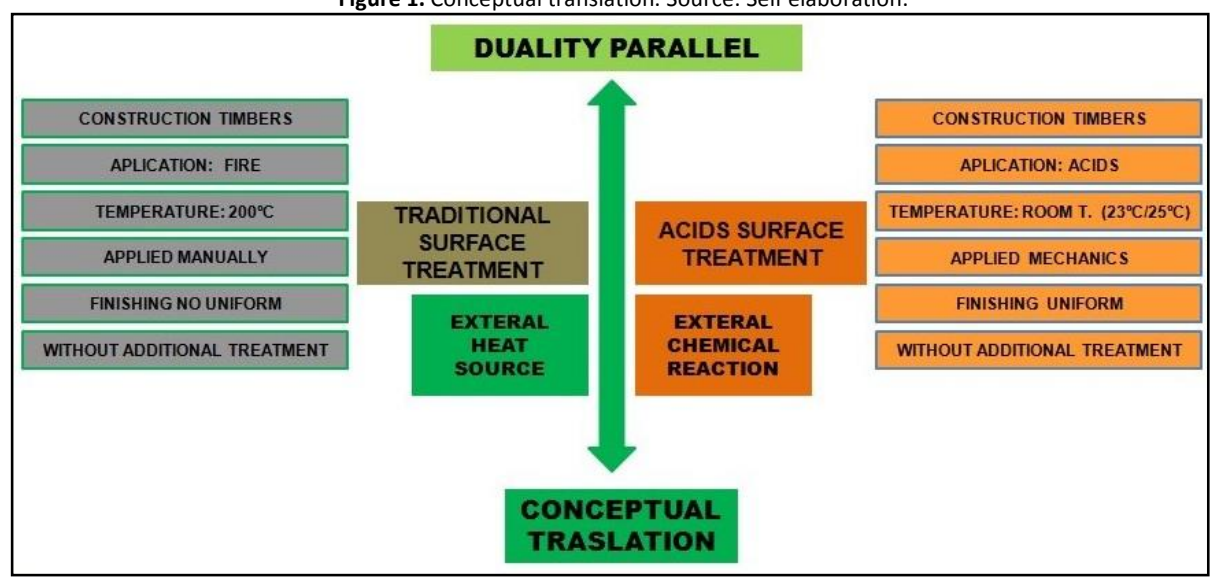

The "conceptual translation" (not only of the materials but also of the productive processes involved) from the traditional treatments using fire to the surface treatments with acids using colorless acids on construction timbers as a method of obtaining new tones to widen the color range of timbers, and being able to include them into the elements that build the architectural space like indoor facings, partitions, latticework, etc. improving their appearance adding value to the architecture (Figure 1).

Using the process of "conceptual translation", we can check the existing parallelism between the options of the superficial traditional treatments using fire and the superficial surface treatments with acids applying colorless acids, this "duality parallel" can also be transferred to the conditionings and characteristic of each superficial treatment, using the fire and the colorless acids, being this last option, when having the acids of a wide variety of types, method to obtain an extension of the range of colors of the construction timbers.

In general terms the superficial treatment of the timbers, can be divided in three groups, the products applied with an external superficial layer like paintings, lacquerers, varnishes, oils, waxes and dyes (several products exist in order to obtain the change of color on construction timbers, even under the denomination of "colorless" (Rodriguez, 2012; Rodriguez, \& García Santos, 2010), there are also other authors that have studied the change of color in other materials (García Santos, \& Conci, 2005; Coronado \& Garcia Santos, 2010).

The products applied that penetrate in the external superficial layer like the lasures and those that modify the structure of the external superficial layer where can include the action of the nature, the traditional surface treatment with fire on construction timbers and the controlled treatment surface with colorless acids on construction timbers.

The first and second group requires a high maintenance since the finishings possess a low superficial hardness and durability and it can degradeate by the action of the ultraviolet rays (uv), on the contrary the third group has a low maintenance and a high superficial hardness and durabilibility (Figure 2).

Figure 2. Surface treatments. Division. Source: Self elaboration.

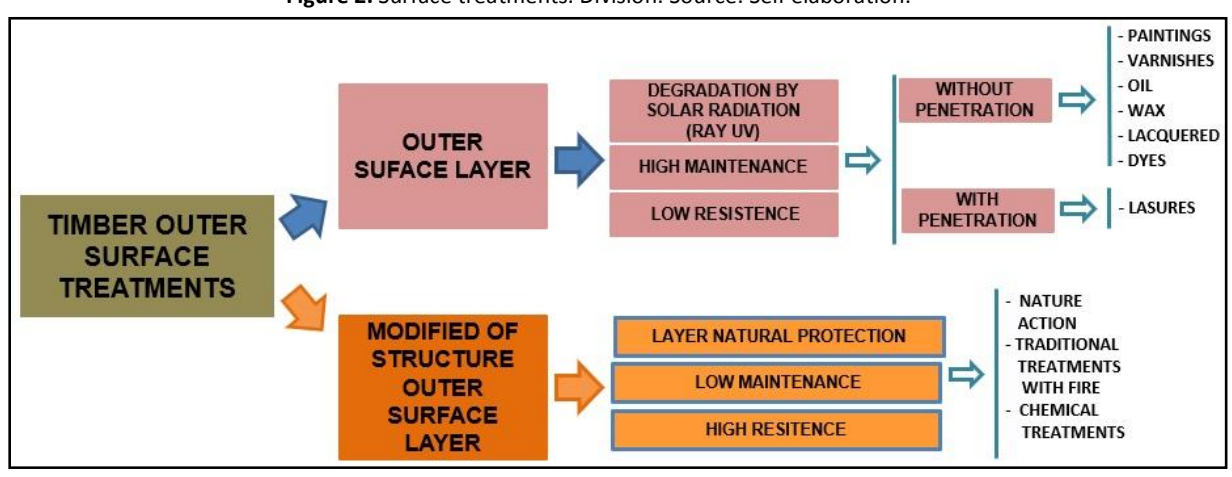


Like method to develop the approach of this research, splits of the description of traditional surface treatment with fire on construction timbers.

The construction timbers like organic material (Asociación Española del Comercio e Industria de la Madera (AEIM), 2017), is subject to multiple conditionings that influence in his final appearance and range of color, among others his species, climate, location, destination or architectural solution more adapted in function of his physical or chemical properties, these variables imply the development of techniques that offer the improvement of his durability and sustainability in through time, that will be defined depending on a suitable treatment, the risk of exposition of the timbers that also influence in his appearance.

\section{Description of surface treatments on timbers}

In nature there are direct actions that modify the structure of the outer surface layer of the timbers and influence their change in appearance, color and texture, to which must be added the timbers drying by the action of the man.

In extremely cold climates, countries that are closer to the North Pole, and by extension have extremely cold weather develop in the trunks of the trees themselves and the elements that color changes are used in traditional architecture effect the extreme cold, influenced not only by the lack of light but also by atmospheric agents like wind generated in its outer layers mineralization freeze them offering a distinctive gray appearance of this type of construction (García Codron, 2011).

In hot countries excess heat may involve a surface heating of the timber to cause exudation of the resin depending on the species of wood affects the surface appearance of the same or if most appropriate oily products that are applied to cold countries, combined with sun exposure and by extension one with excessive heat on the surface, the wood generates "cold or boiling" affected their condition. Also, excess heat to generate the evaporation of water contained in the cells, when exiting destroys surface protection applied to these. The durability of wood interior is influenced by aging, affecting it's color and it's alteration over time (Álvarez Noves \& Seoane, 1982).

Ultraviolet radiation burns cells wood surface, but without heating the same. The effect is a graying and peeling of wood, more marked in red woods such as teak or iroko. Ultraviolet radiation is reflected in the brown and dark tones of the spectrum, a property that is used to protect wood by applying a superficial pigmentation. The timber color change is basically a reaction surface by a photooxidation process, caused by UV radiation, altering the color and properties of timbers.

The penetration of light into the layers of wood is less than 75 microns, when it comes to UV light and 200 microns in the case of visible light. The color change, however, may affect more deeply, by the reactions resulting from the consequent alteration, resulting in loss of gloss and increased surface roughness. The ultraviolet part of solar radiation is the main cause of the disturbance suffered by wood surfaces and coatings applied over it. The coatings applied on wood, usually varnishes, are not safe from this alteration of the characteristics of the timbers (Jimenez Peris, 1969).

Infrared radiation heats the surface of the wood, but without burning. Evaporates the water contained in the cells of the resulting surface tensions inside the timber they produce cracks, combined with warps. The effect of this infrared radiation is reflected by the light colors of the spectrum (Lamps, 2007).

The action of drying wood by the action of man is confined to technologies that have ranged from the traditional method of simply gathering of cut wood outdoors as a means of dimensional stability and color of it to industrial production methods for a short time drying considerable volume of wood using techniques such as heat pumps, vacuum drying with superheated steam. There are also studies on drying by use of ultrasound and infrared radiation or using only infrared lamps which transmit heat as electromagnetic radiations, all these methods in more or less influence by extension in appearance, since the drying itself involves dehydration thereof inevitably affect its color and color gamut (Álvarez Noves \& Fernández Golfin-Seco,1997).

The best known of the wood protection technique by surface treatment with fire is the Shou-sugi-ban Japanese origin is carried out by surface burning wooden boards (burned or charred), currently applied by torches controlled temperature, a surface brushed, washed with water and giving the end impregnation with natural oils, which is usually renewed annually. This technique has been used in renovation of historic wooden buildings in recent decades as an option to obtain a desired surface finish (Emerson, Mcdonald, Hayatsu, Trommler, Nishimura, Ross \& Raven Row, 2010). 
The behavior of timbers under fire, the traditional surface treatment with fire on timbers and the surface treatment with colorless acids on timbers are described.

\section{Behavior of the timbers under the fire}

In the analysis of the behavior of the timbers under fire has to take into account factors as the density of the timbers that varies in function of its species, being the greater densities those that have a better behavior under the fire, being his start and combustion slower (Boonstra, Rijsdijk, Sander, Kegel, Tjeerdsma, Militz, Van Acker, \& Stevens, 2006; Mauro, \& Balarezo, 2014). The relation between the surface and volume of the timbers piece that increases the probability of propagation under the same this circumstance has been founded by comparing the behavior of kindling with pieces of the trunk of the trees. The existing irregularities in the timbers is an anisotropic material, his conditions are not uniform we may find cracks, fissures, knots, etc. that are an unfavorable factor in case of contact with the fire, especially if the irregularities go in the same direction of the fibers of the timbers.

The timbers when being a material of low conductivity does not burn quickly and is this low thermal conductivity that transmits in the case of a charred superficial of the timbers a low proportion of heat to the interior of the timbers that protects it in the future of aggressions. This charred external layer acts as an insulator protection of the interior of the timbers piece, acting like insulator and keeping its physical and mechanical properties (Emerson et al., 2010).

The temperatures that can be reach when the timbers are in contact with the fire are of about $270^{\circ} \mathrm{C}$ that it is when they begin to give off steams of the timbers, with direct flame the timbers begin to burn at $300^{\circ} \mathrm{C}$ and $400^{\circ} \mathrm{C}$ without direct flame, these temperatures apply to the traditional surface treatments with fire on the timbers (Quintáns, 2010).

\section{Traditional surface treatment with fire}

In a point with lower intensity finds the traditional surface treatment with fire on timbers, that in lower measure arrives to carbonize the superficial face of the timbers, to obtain greater durability of the same (like example of this traditional method have the manufacture of wine barrels).

The three types of most common surface treatments with fire on the construction timbers are the following: "light" that it is little used and that realized surroundings to the $115^{\circ} \mathrm{C}$, one "half" with a temperature of $200^{\circ} \mathrm{C}$ and one "strong" surroundings to the $230^{\circ} \mathrm{C}$, in function of the level of treatments obtains diverse properties in the timbers and between the substances that influence in the color of the timbers.

Although they use some systems of control of the temperature by means of sensors, is the hand of skilled work, whose experience and continuous manual control of the process fixes the final result of the finishing of the timbers. (Figure 2).

\section{Surface treatments with acids}

Although we can initially thing that the application of an acid on the timbers can be a disadvantage this circumstance transforms into a virtue from the moment that the acid applied superficially under control provides a layer that changing the color of the timbers and improving his appearance, so that it guarantees the homogeneity or uniformity in the modification of the color in all the surface of the timbers treated.

The application of the acids directly on the superficial faces of the timbers cut and sanded, without any type of previous treatment, suppose a modification of the color of the timbers, apply in conditions of environmental temperature for construction timbers.

In the case of colorless acids in liquid state, achieves a homogeneity or uniformity in the application on the surface of the construction timbers and besides do not need a back application with another treatment of protection for the timbers, as in the traditional treatments (Figure 3).

\section{Advantages of the surface treatments with acids}

In addition to the exposed, the surface treatments with acids presents a several advantages against the traditional surface treatments with fire that are described below: 
Considering the above a "parallel duality" is established between the traditional treatments with fire and the surface treatments with acids by observing the change in the productive method: the modification of the construction timbers applying colorless acid, understood as the activation of a chemical reaction which acts like a source of external energy that applied on the surface of the timbers produces a surface treatment with colorless acid alternative to the traditional treatments with fire.

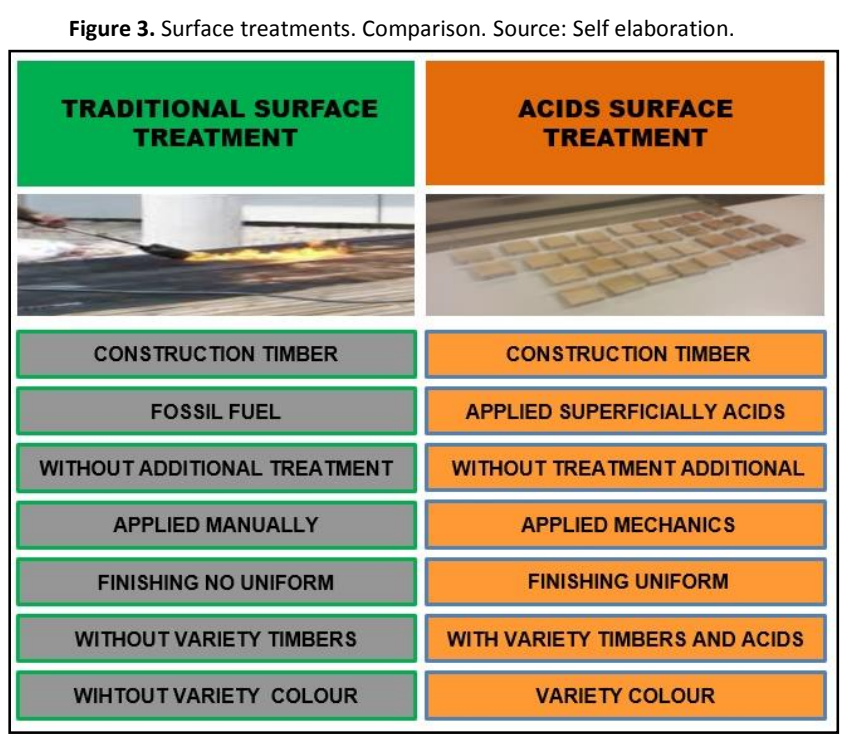

As mentioned at the beginning of this research, the superficial treatments that do not modify the external superficial structure are subject to the decreasing of its superficial hardness and to degradation due to the UV rays and requires a high maintenance whereas those modified in their external superficial surfaces structures, by the contrary, need a low maintenance and keep a high superficial hardness.

\section{Production}

Among the characteristics of the traditional treatments using fire, we highlight that it is a manual productive process that can only produce a limited number of units, and the control of the process is in the hands of the workforce and therefore does not have the performance that the mechanical processes have. This circumstance also affects the final product that being correctly finished does not meet the standards of uniformity in the production.

The storage of the generated production of timbers by the surface traditional method with fire is also influenced by the conditions derived of using a process that uses fire, as storing timbers can activate a fire caused by an ember, due to the temperature inside the timbers.

The surface treatments with colorless acids involves a substantial change from the point of view of the process or industrial process of the external superficial treatment of the timbers, where it is easier to reach an industrial production, developing the processes of production mechanised form, having control over the parameters of control of materials, temperature, exposure, intensity of color, thickness of the generated layer, integrity of the timbers, uniformity, energetic saving, easy of the industrial application of colorless acids in liquid state and security, considering that the traditional processes using the fire are subject to variables like the internal heat that accumulate internally and that they can trigger uncontrolled fires (Figure 4).

Figure 4. Diagram of production. Comparison. Source: Self elaboration.

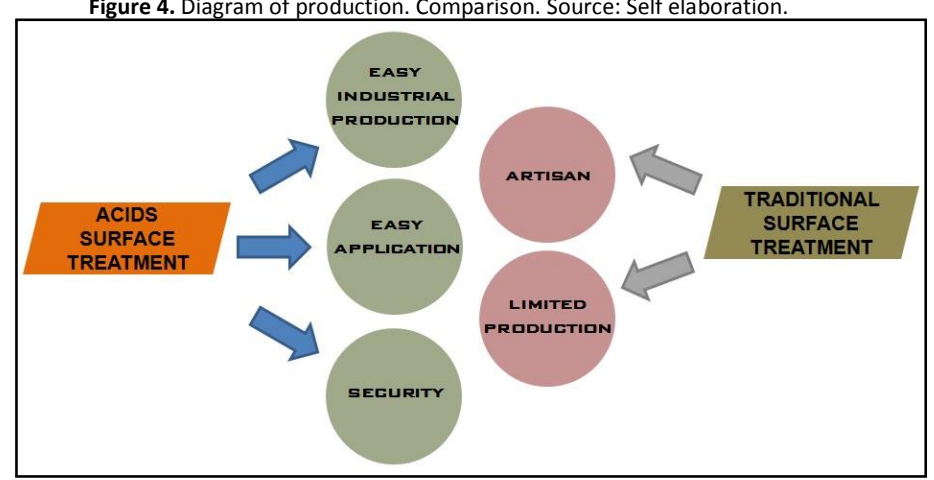


The characteristics of the traditional application of acids on construction timber are limited to improving the functional characteristics of the timbers, understood as a functional improvement, for the purposes of dimensional stability or protection against atmospheric and biological agents, fire protection or cleaning (Mauro \& Balarezo, 2014; Novoa Robles, 2006; Özçifçi, Uysal, Kurt, \& Özbay, 2009; Petric, 2013), normally not being applied externally and superficially and not being its objective to modify the color of the timber.

No previous researches have been found on colorless acids in liquid state with the objective of investigating the surface chromatic variation produced by the surface application of colorless acids in liquid state on construction timber, to extend the range of surface color of construction timber nor the uniformity of the color histograms of the RGB color space an additional reason why this research is original.

Researches on color change in timber generally study color change due to its drying in an outdoor environment and prior to its final storage (Villegas, 2009; Sundqvist, 2002; Sandoval, Torres, Franc Oise \& Puiggali, 2012; Boonstra, et al., 2006), but color change is not studied after the timber is stored and before being prepared to be marketed, therefore those researches do not focus on the final surface finish of the color of the construction timber to be marketed.

\section{Description of the Problem}

As a starting point of the description of the problem, the description of the traditional surface treatment with fire and the surface treatment with colorless acids on the construction timbers (developed by the authors) are established in this research and its situation on general scheme of surface treatments of the timbers (Figure 2).

The problem is that the traditional surface treatment with fire is limited to improving the functional characteristics of the timbers but does not allow a surface uniform distribution of the timbers nor an extension of the range of colors of the construction timbers, but the timbers are darkened by reaching black, losing their chromatic wealth by extension.

Methodology

The methodology used describes the traditional surface treatment with fire and the surface treatment with colorless acids process and finally the methodology and the comparison of histograms.

\section{Traditional surface treatment with fire}

The essays have been developed in the laboratory of building materials ETSAM (UPM), where they are deposited, and the samples are treated in indoor conditions at $25^{\circ} \mathrm{C}$ and $36 \%$ relative humidity.

For mechanical processing of timbers, it has been used brush cutter machine, linear cutting machine, cross cutting, sanding etc. to produce timbers samples for further treatment.

Three timbers of the same species have been selected, boards of these timbers were obtained and mechanically processed to get samples of homogeneous dimensions of $36 \mathrm{~cm}^{2}$ of surface and $1.5 \mathrm{~cm}$ thick, that were then marked for identification.

The surface treatments with fire used was the "half" type with a temperature of 200 ㄷ for 3.5 minutes and at distance of 30 centimeters and previously vaporized them with water, it is applied by natural gas cartridge and blowtorch in specific room for the essays.

\section{Surface treatments with acids}

The essays have been developed in the same indoor conditions, relative humidity and mechanical processing of timbers that the traditional treatment with fire.

Three timbers of the same species have been selected, boards of these timbers were obtained and mechanically processed to get samples of homogeneous dimensions of $36 \mathrm{~cm}^{2}$ of surface and $1.5 \mathrm{~cm}$ thick, that were then marked 
for identification, providing a perimeter plastic sheet to contain in its surface the colorless acids in liquid state is obtained in order study the timbers sample.

For surface application of colorless acids in liquid state has been used a laboratory hood, plus common tools for making gloves trials nitrile, goggles, gown, mask, pipette calibrated in milliliters and mechanism propipette product extraction.

The methodology employed for the surface application of colorless acids in liquid state is described as follows: 3 milliliters are poured by milliliter calibrated pipette and mechanism propipette product extraction at room temperature of $25^{\circ} \mathrm{C}$ under a laboratory hood, pouring it on the surface of the sample to be treated uniformly, being contained by a perimeter plastic sheet previously arranged and subsequently deposited in the space reserved in the laboratory for storage. A volume of 3 millilitres of acids is used, because it is the most suitable volume observed that allows a sheet of acids on the sample tested without getting to soak the timber, and so that it only affects the surface layer of the timber sample.

\section{Methodology of imaging}

For the realization of the photos has been used a table photo shooting of samples, composed of board with reference grid, column graduated in millimetres and with four lighting energy saving lamps $23 \mathrm{~W}$ (115W) and 6,400 k color temperature (daylight) and a photo camera Nikon Coolpix P-100 subject to the column of table photo shooting.

\section{RGB color space. Histograms and chromatic variation}

For study the uniformity of the color surface samples through the traditional treatment with fire and the traditional treatment with colorless acids, RGB color space is used.

The choice of RGB color space is based that the RGB color space being a more restrictive space in terms of color range, allows differentiation better of the colors for the human eye. The RGB space uses histograms of colors red, green, blue and brightness or luminosity to represent the chromatic variation and the uniformity of the surface color timbers by treatments is used.

The procedure for obtaining images before and after being treated timbers sample and observing the chromatic variation and the uniformity of the surface color timbers of the samples, they are the same of the traditional surface treatment with fire and the surface treatment with colorless acids in liquid state described below.

Both untreated and treated original samples were photographed on the table photo shooting provided with 4 lateral energy saving lamps setting the same conditions jacks photos, both untreated samples as once treated photographed, then placed the camera on the table photo shooting, in which, at its base the specimen timbers at a fixed distance from the upper face thereof to the camera lens is placed, and the sample timbers is placed in the table top face being in front of the camera and this is always fired under the same conditions, obtaining a complete picture of the sample.

Once available image proceeds to view by computer program, cropping the image around the perimeter of the sample, eliminating the areas outside the sample, then a grid on the sample is projected, which are obtained the histogram data belonging to the RGB color space. In the grid obtained a central area of the same size in all samples is selected by said histogram projected on to a representation of cartesian coordinates by rule or bar graph representing the number of pixels of the image for each value of color intensity level of red, green, blue and brightness or luminosity, placing on the axis of abscissa (horizontal) different intensities levels of color or tones divided into 256 columns, placing the "black" value (0) on the left and the "white" value (255) on the right and on the vertical axis (vertical) where the height of each of the columns of histogram determines the number of pixels from each value of color intensity level or color tone of red, green, blue and brightness or luminosity separately, to then compare the values obtained proportionally and observe the chromatic variation and the uniformity of samples, through the analysis of the results.

\section{Results}

The results of this research are part of a campaign of more than 500 corresponding essays part of a wider research, that comprises the application of 15 colorless acids in liquid state to 34 different species of timbers of diverse 
continents and different botanic divisions. For this research 45 essays with colorless acids and 12 essays with fire were conducted, in both cases to compare 3 timbers of the same species. To study the uniform distribution of the surface color and uniformity to compare the surface treatments with acids with the traditional treatments with fire, the histogram of color red, green, blue and brightness or luminosity are used, theses histograms generates a "curve", which "width" is defined in the sample we can observe a greater variation value from the black (located on the left zone of the picture) to the white (situated on the right zone of the picture), that is to say that "the narrower the curve" is more uniform is the color and " the wider the curve" is less uniform is the variation of color. As an example, the histogram of brightness or luminosity is used below (Figure 5).

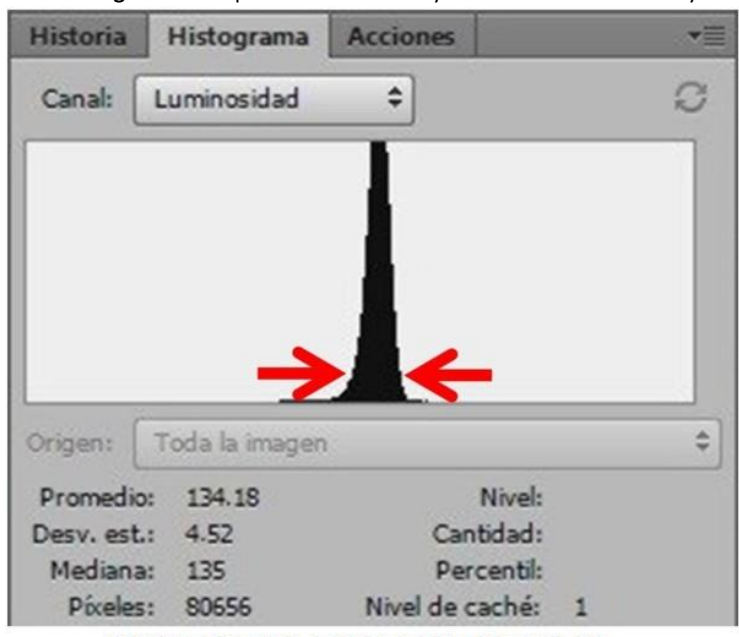

UNIFORM DISTRIBUTION

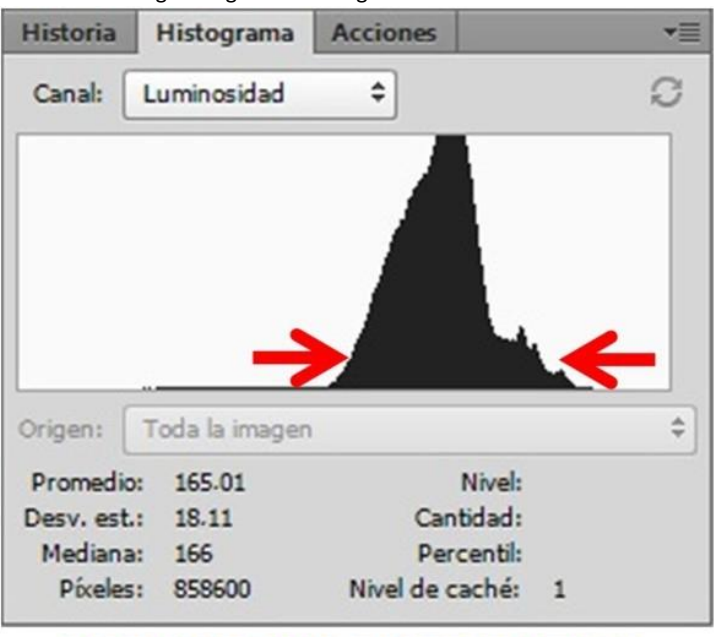

NONUNIFORM DISTRIBUTION

A comparison method is established by the authors for this research consisting of applying a rule or bar graph on the horizontal axis of the histogram between the value 0 and the value 255 and drawing a line halfway up the height of the vertical axis that cuts the histogram, then draw two parallel lines that will establish two values of color intensity level or color tone of red, green, blue and brightness or luminosity on the horizontal axis of the histogram, whose difference will establish the width or "section" of that histogram. This procedure will be repeated in all histograms of color of red, green, blue and brightness or luminosity of samples treated or untreated with traditional surface treatment of fire or the surface treatment with colorless acids in liquid state. As an example, the histogram of brightness or luminosity is used below (Figure 6).

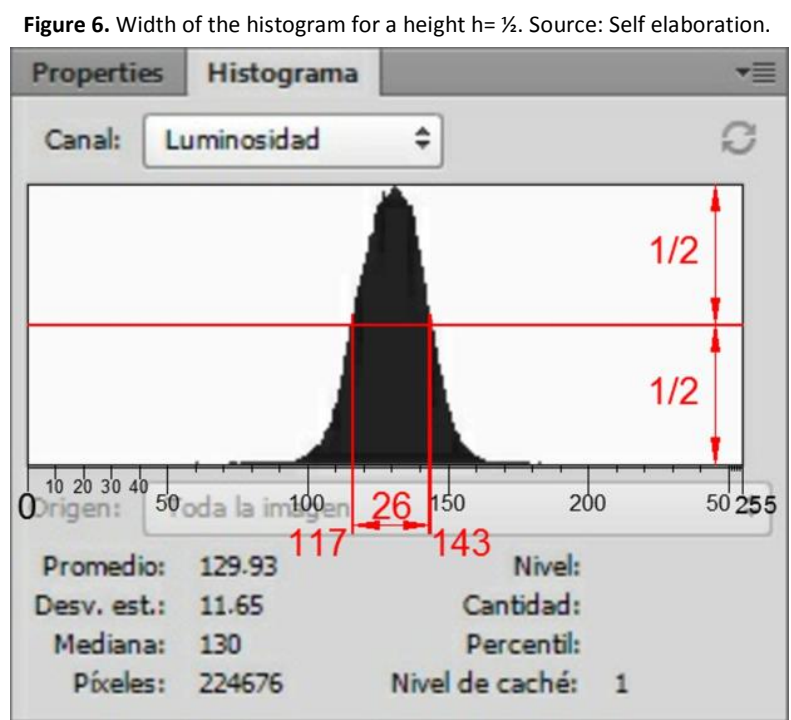

The following results in function on the difference of width of the histogram have been obtained between the surface treatment with colorless acids and the traditional surface treatment with fire on 3 timbers of the same species (Table 1 and Table 2). 
Traditional surface treatment with fire

Average values of width difference of histograms Blue, green, red and luminosity

\begin{tabular}{lcccccccccccccc}
\hline WHITE & & & & \multicolumn{1}{c}{ WHITE } & & & & RED AME. & & \\
AME. OAK & B & G & R & L & EUR. OAK & B & G & R & L & OAK & B & G & R & L \\
\hline M28_ST1 & 24 & 38 & 43 & 40 & M29_ST1 & 15 & 19 & 19 & 13 & M30_ST1 & 23 & 26 & 36 & 25 \\
M28_TT1 & 15 & 24 & 36 & 29 & M29_TT1 & 27 & 25 & 31 & 34 & M30_TT1 & 28 & 47 & 46 & 58 \\
M28_DF1 & -9 & -14 & -7 & -11 & M29_DF1 & 12 & 6 & 12 & 21 & M30_DF1 & 5 & 21 & 10 & 33 \\
M28_\%DF1 & -38 & -37 & -16 & -28 & M29_\%DF1 & 80 & 32 & 63 & 162 & M30_\%DF1 & 22 & 81 & 28 & 132 \\
M28_ST2 & 22 & 35 & 40 & 36 & M29_ST2 & 23 & 28 & 30 & 32 & M30_ST2 & 22 & 30 & 45 & 27 \\
M28_TT2 & 25 & 45 & 69 & 59 & M29_TT2 & 19 & 31 & 28 & 28 & M30_TT2 & 36 & 67 & 53 & 44 \\
M28_DF2 & 3 & 10 & 29 & 23 & M29_DF2 & -4 & 3 & -2 & -4 & M30_DF2 & 14 & 37 & 8 & 17 \\
M28_\%DF2 & 14 & 29 & 73 & 64 & M29_\%DF2 & -17 & 11 & -7 & -13 & M30_\%DF2 & 64 & 123 & 18 & 63 \\
M28_ST3 & 18 & 24 & 36 & 36 & M29_ST3 & 25 & 24 & 37 & 29 & M30_ST3 & 16 & 17 & 21 & 23 \\
M28_TT3 & 19 & 30 & 29 & 31 & M29_TT3 & 27 & 63 & 73 & 75 & M30_TT3 & 28 & 38 & 34 & 39 \\
M28_DF3 & 1 & 6 & -7 & -5 & M29_DF3 & 2 & 39 & 36 & 46 & M30_DF3 & 12 & 21 & 13 & 16 \\
M28_\%DF3 & 6 & 25 & -19 & -14 & M29_\%DF3 & 8 & 163 & 97 & 159 & M30_\%DF3 & 75 & 124 & 62 & 70 \\
M28_ST4 & 24 & 32 & 35 & 38 & M29_ST4 & 20 & 23 & 31 & 30 & M30_ST4 & 25 & 22 & 39 & 28 \\
M28_TT4 & 15 & 22 & 25 & 27 & M29_TT4 & 21 & 34 & 38 & 33 & M30_TT4 & 34 & 50 & 43 & 58 \\
M28_DF4 & -9 & -10 & -10 & -11 & M29_DF4 & 1 & 11 & 7 & 3 & M30_DF4 & 9 & 28 & 4 & 30 \\
M28_\%DF4 & -38 & -31 & -29 & -29 & M29_\%DF4 & 5 & 48 & 23 & 10 & M30_\%DF4 & 36 & 127 & 10 & 107 \\
M28\% & -14 & -4 & 2 & -2 & M29\% & 19 & 63 & 44 & 79 & M30\% & 49 & 114 & 29 & 93 \\
\hline
\end{tabular}

(M28) Timber 28; (ST) Untreated sample 1; (TT) Treated sample 1; (DF1) Average difference sample 1; (\%DF1) Percentage average difference value sample 1; (M28\%) Average difference values of timber 28;(B) Blue; (G) Green; (R) Red; L (Luminosity)

Table 2. Surface treatment whit colorless acids. Percentage average values. Width difference of histograms. Source: Self elaboration. Surface treatment with colorless acids in liquid state Percentage average values of width difference of histograms Blue, green, red and luminosity

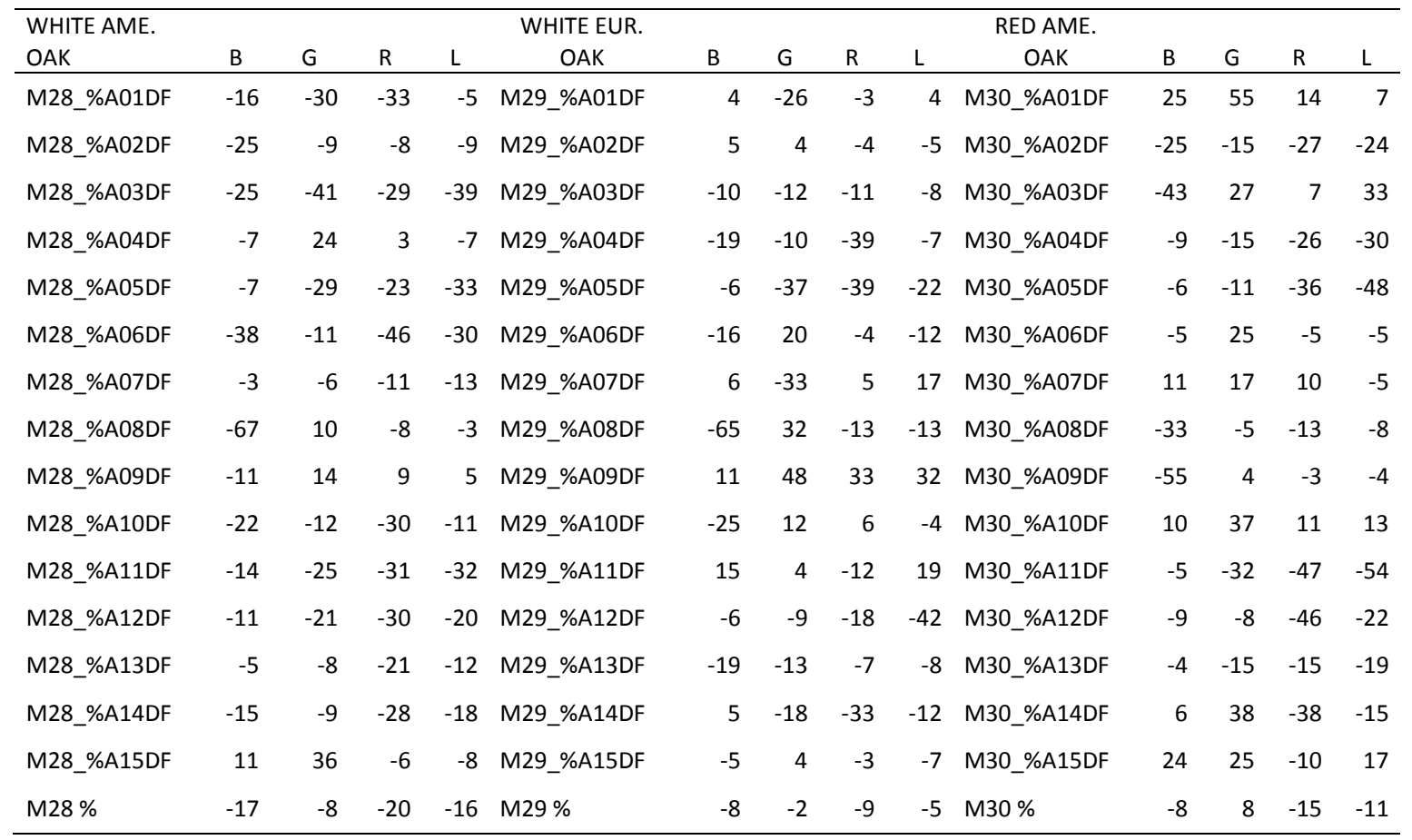

M28_\%A01DF = (M28) Timber 28; (\%A01DF) Percentage average difference values with acid A01. (M28\%) Average difference values of Timber 28, (B) Blue; (G) Green; (R) Red; L (Luminosity). 
As an example, in the Figure 7 the change of color is observed when applying the traditional treatment with fire and the surface treatments with colorless acids in the histogram of brightness or luminosity.

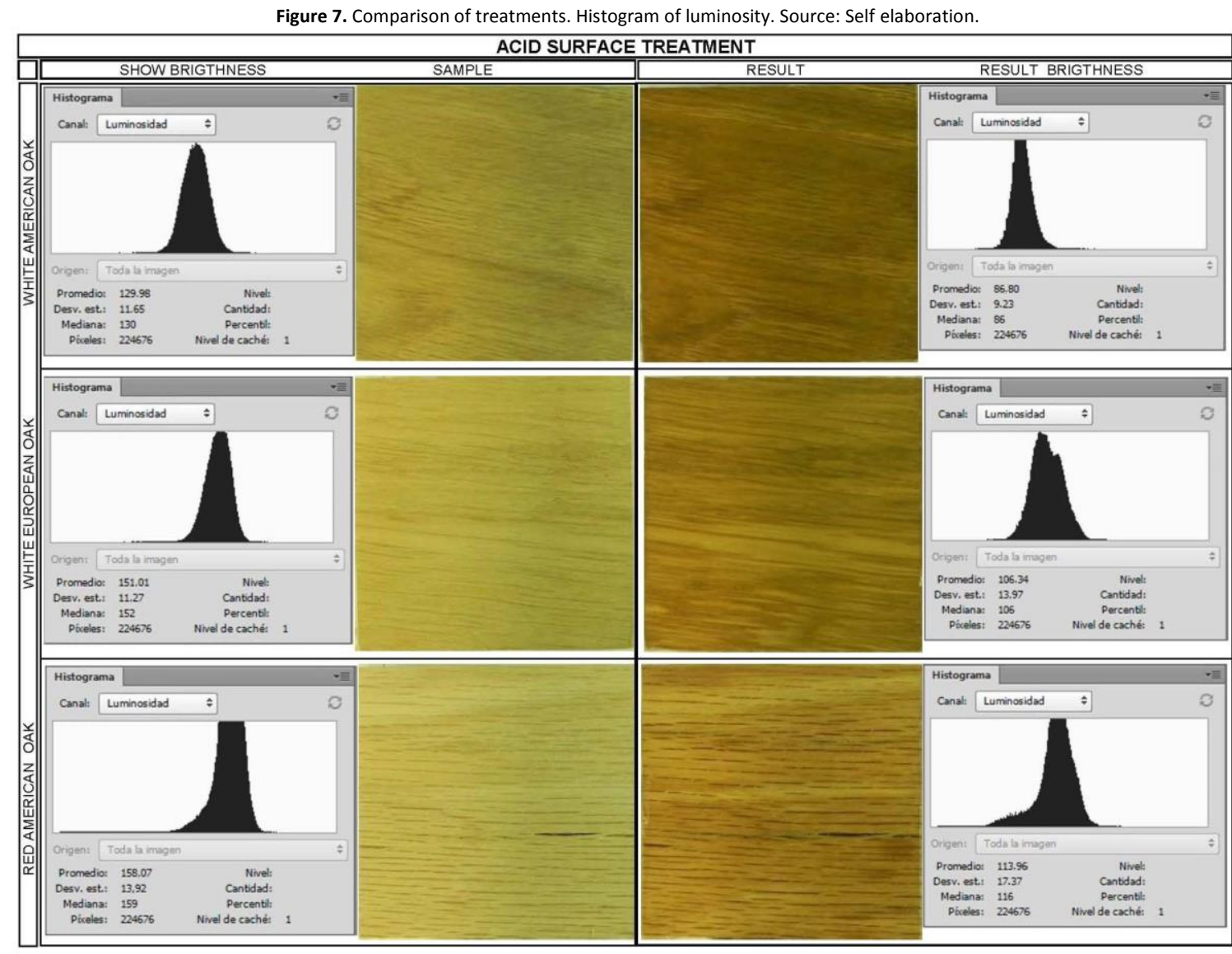

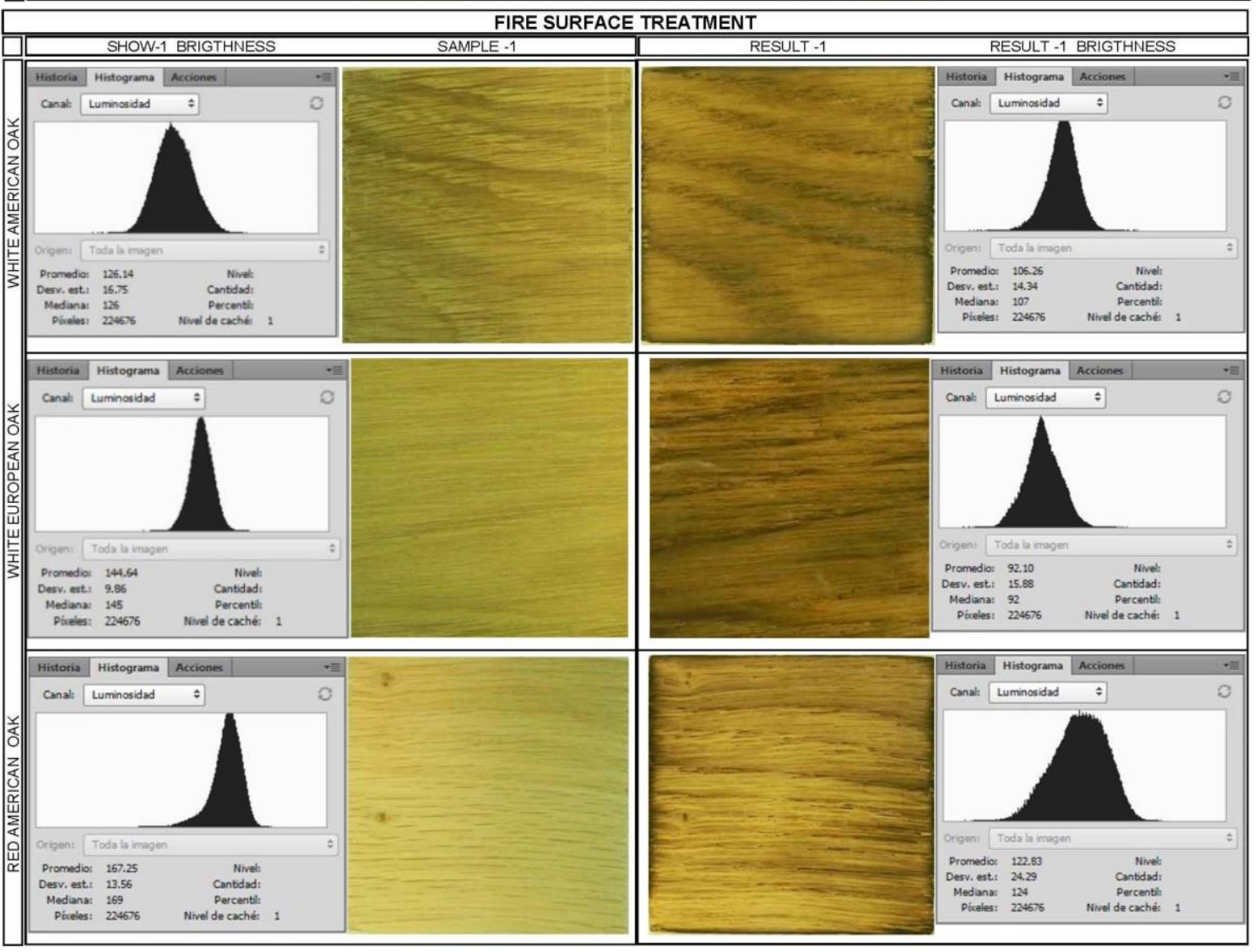


The attachment of the histogram of brightness or luminosity of RGB color space, fixing the curves "without applying colorless acid" detailed as "sample" and the sample treated with colorless acid, detailed as "result", in the same way to compare make the same procedure with the samples of the traditional treatments, without applying fire and applying fire (Figure 7).

The observation of the different timbers samples to which we have applied fire with a blowtorch and previously vaporized them with water, to avoid charring it, to obtain the traditional surface treatments with fire, achieving the corresponding curves of histogram of brightness of the sample "result".

These curves are in general terms "wide", therefore we can derive that they have a lower uniformity in the color, that in the case of using the surface treatments with colorless acids.

Also, in both treatments are observed the variation of the chromatic change and of the change of the tonality of the timbers that tends to darken.

In the samples presented above differences are observed between the treated timbers and the one without treatment in the change of color, the uniformity of the color, the timbers of traditional treatments with fire has small charred zones because the flame does not generate uniform surfaces, the difference of manual application by the own conditions of the different methods that allows in a case when treating of colorless acids that his application was a uniform plate in front of the application with blowlamp of the traditional surface treatments with fire that depends on the distance, intensity and time of exhibition, and by extension involves a workforce.

\section{Discussion}

The traditional treatment with fire in the Table 1, the process of obtaining the percentage average values of width difference of histograms blue, green, red and luminosity is presented of 3 timbers of the same species, with 4 essays by timber, measuring the histograms as explained in Figure 6 and obtaining the values of the treated and untreated samples, to later obtain the difference and finally the percentage average values of width difference of histograms.

The surface treatment with colorless acids in the Table 2, the percentage average values of width difference of histograms of 15 colorless acids applied on 3 timbers of the same species as those in Table 1.

In Tables 1 and 2, the negative values represent the narrowing of histograms and positive values represent the expanding of histograms.

A positive value represents a nonuniform distribution of color histogram and a negative value represent a closer value to a uniform distribution of color histogram. From Tables 1 and 2 the results of the percentages total average values of each timber of the same species are obtained, finally the percentages total average values of the three combined timbers is obtained and they are represented in Table 3.

Table 3. Comparison surface treatments. Percentages total average values. Width difference of histograms. Source: Self elaboration.

\begin{tabular}{lcccc}
\hline $\begin{array}{c}\text { Comparative surface treatment percentages total average } \\
\text { values of width difference histograms } \\
\text { blue, green, red and luminosity }\end{array}$ \\
\hline Treatment & B & G & R & L \\
Fire & 18 & 58 & 25 & 57 \\
Acids & -11 & -1 & -15 & -10 \\
\hline
\end{tabular}

The traditional surface treatment with fire obtains values of positive total average percentages, which means that its distribution is not uniform, with higher values in green and luminosity histograms and lower in blue and red histograms.

The surface treatment with colorless acids in liquid state obtains values of negative total average percentages, which means that its values represent a closer value to a uniform distribution of color histogram, with similar values in blue, red and luminosity histograms and lower in green histogram. 
The color histograms of the RGB color space are compared of both treatments and it is concluded that the controlled surface treatment of colorless acids in liquid state on construction timbers obtains a more uniform distribution of color histograms than the traditional surface treatment with fire.

\section{Acknowledgments}

The authors would like to thank the Laboratory of building materials of Escuela Técnica Superior de Arquitectura de Madrid (ETSAM) of UPM, belonging to the Universidad Politécnica de Madrid (UPM) as a place of conservation of the samples and the realization of the essays.

\section{References}

Asociación Española del Comercio e Industria de la Madera (AEIM). (2017). Documentos técnicos. Madrid. España. www.aeim.org

Álvarez Noves, H. \& Seoane, J. (1982). Fotodegradación de la madera. Asociación de Investigación de Industrias de la Madera (AITIM). 108. Available online at: http://infomadera.net/uploads/articulos/archivo_1153_17037.pdf

Álvarez Noves, H. \& Fernández Golfin-Seco, J.I. (1997). Manual de secado de la madera. Asociación de Investigación de Industrias de la Madera (AITIM). Madrid, España, ISBN 84-87381-15-4.

Boonstra, B.; Rijsdijk, J.; Sander, C.; Kegel, E.; Tjeerdsma, B.; Militz, H.; Van Acker, J.;Stevens, M. (2006). Microstructural and physical aspects of heat treated timber. Part 1. Softtimber. Maderas, Ciencia y Tecnología, 8(3), 193-208.

Coronado Martin, J. \& Garcia Santos, A. (2010). La influencia de los productos hidrofugantes en las modificaciones cromáticas del ladrillo cerámico. Materiales de Construcción, 61(304), 597-611.

Emerson, T., Mcdonald, S., Hayatsu, T., Trommler, K., Nishimura, R. \& Ross, J. (2010). Raven Row. Lignum Facile, 6-7. Available online at: meetingpointlignum.com/arquitectura_y_madera/lignum\%20facile-doc-514-47.pdf

García Codron, J.C. (2011). Curso Programa Senior. Las regiones naturales de la Tierra s-307. Biogeografía. Tema 3. Los seres vivos en las regiones frías de altas latitudes. Departamento de Geografía, Urbanismo y Ordenación del Territorio. Escuela Técnica Superior de Ingeniería de Caminos, Canales y Puertos. Universidad Politécnica de Madrid (UPM). Available online at: https://ocw.unican.es/mod/resource/view.php?id=991

García Santos, A. \& Conci, M. (2005). Variación del color del soporte cerámico tratado con barniz antigraffit. Materiales de Construcción, 55(278), 55-68.

Jiménez Peris, F.J. (1969). Efectos de las radiaciones ultravioletas en las maderas. Asociación de Investigación de Industrias de la Madera (AITM). 37. Madrid, España. Available online at: http://infomadera.net/uploads/articulos/archivo_374_16294.pdf

Lamps. C.V. (2007). Emisores infrarrojos. Web de empresa. Barcelona. España. Available online at: www.cvlamps.com/emisores.htm

Mauro F. \& Balarezo R. (2014). Retardantes de llama (parte 2). Instituto Nacional de Prevención, Salud y Seguridad Laborales (INPSASEL).Caracas,Venezuela. if.no v-13310614-2. Registro Inpsasel.07 13310614. Available online at: https://vdocuments.site/retardantesllama-mauro-balarezo-2.html

Novoa Robles, L.A. (2006). Programa de desarrollo de políticas de comercio exterior 1442/oc -pe. Consultoría de secado y preservación de madera aserrada. Ministerio de Comercio Exterior y Turismo (Mincetur) Banco Interamericano de Desarrollo. 1-36. Lima, Perú. Available online at: https://www.mincetur.gob.pe/wp-content/uploads/documentos/comercio_exterior/Sites/Bid/pdfs/INFORME\%20FINAL.pdf

Özçifçi, A. Uysal, B. Kurt, S. \& Özbay, G. (2009). Impact of various fire retardants on the red colour and yellow colour tone of some woods and varnishes. Karabuk University. Technology, 12(4), 267-274.

Petric, M. (2013). Surface modification of wood: a critical review. Rev. Adhes. Adhes., 1(2), 216-47.

Quintáns, C. (2010).Madera y Fuego. Documentos Técnicos. Revista Lignum Facile. 1-10. Referencia: 110115.RC01.01020304.0102. Available online at: www.contrafort.cat/bioconstruccio/Rf-0.pdf. Revista Lignum Facile. Santiago de Compostela.España. www.clustermadeira.com

Rodriguez, A. (2012). Materia informada: influencias de los barnices incoloros en las propiedades superficiales de las maderas de construcción. Tesis Doctoral. Universidad Politécnica de Madrid (UPM). Escuela Técnica Superior de Arquitectura de Madrid (ETSAM). Madrid, España. 354 p. Available online at: http://oa.upm.es/14842/1/ANTONIO_RODRIGUEZ_RODRIGUEZ.pdf

Rodríguez Rodríguez, A., García Santos, A. (2010). The classification, characterization and chromatic descomposition analisys of colourless varnishes, applied to wood used in construction. 370 IAHS Word Congress on Housing Science "Desing, Technology, Refurbishment and management of Buildings". Santander, España, 26-29 Octubre. Code 174, p. 111. ISBN: 978-84-693-6655-4.

Sandoval, S., Torres. W.J., Franc Oise, M., Puiggali, J.R. (2012). Colour alteration and chemistry changes in oak timber (Quercus pedunculata Ehrh) during plain vacuum drying. Timber Sci. Technol., 46, 177-191. 
Sundqvist, Bror (2002). Colour response of scots pine (Pinus sylvestris), norway spruce (Picea abies) and birch (Betula pubescens) subjected to heat treatment in capillary phase. Holz Roh- Werkst 60, 106-114.

Villegas, M.S. (2009). Colorimetría y blancura en madera de salix. Facultad de Ciencias Agrarias y Forestales, U.N.L.P., CC. (31): 1900. La Plata, Buenos Aires, Argentina. Available online at: http://studylib.es/doc/5172289/colorimetr\%C3\%ADa-y-blancura-en-madera-de-salix-villegas-m.s. 